\title{
MICRO-REGIONALISATION OF A TOURIST DESTINATION - A MODEL FOR A SUSTAINABLE DEVELOPMENT OF A TOURIST DESTINATION ON THE EXAMPLE OF BOTEVGRAD MUNICIPALITY
}

\author{
D. Alexova \\ International Business School, Botevgrad, Bulgaria
}

\begin{abstract}
The survey includes a study of destination planning and development at a local level through microregionalization. The subject of this work is the study, analysis and definition of opportunities for sustainable tourism development at a local level as a model that can be multiplied to be used in other developing tourist destinations. The objective of the study is the sustainable development of tourism in the municipality of Botevgrad and its positioning as an attractive tourist destination. To achieve the research goal, a set of general and private methods corresponding to the interdisciplinary and heterogeneous nature of the study are used: methods of analysis and synthesis, cameral method, cartographic method, geographic methods of research: spatial analysis of the resource potential, localization of the surveyed sites. An approach of studies and systematization of information on literary sources and planning documents has also been used; collecting, processing, systematizing and interpreting statistical data and documents; critical analysis method and expert assessment; comparative analysis method; scientific analysis and synthesis; field observation. The main conclusions point the opportunities for destination management at a local level through micro-regionalisation as a successful model for sustainable tourism.
\end{abstract}

Key words: sustainable tourism, tourist resources, regional development, destination management, tourist zone, tourist core, tourist location, tourist point

\section{INTRODUCTION}

The regional development of tourism depends to a large extent on the public sector's involvement, as this business is too much integrated with other public services, the state of the transport infrastructure, access towards and to tourist attractions and sites, cleanliness, security. The presence or absence of projects supporting tourism infrastructure on a given territory is essential for the competitiveness of tourism. Therefore, the policy of the municipal authorities and their attitude towards the issues of the sector are among the key factors for the development of a tourist destination.

In Botevgrad municipality the tourist services sector is not developed in line with the national proportions, at the expense of a wellfunctioning economy with an industrialagrarian structure. The up-to-dateness of the topic is related to the unrecognizable and inefficient use of the tourist resources in Botevgrad Municipality. Traditionally, the municipality is developed as an industrial one, characterized by low unemployment, which, along with the historical premise, explains the lack of entrepreneurial needs on the part of the local population. Tourism is included in the vision of programming documents and is on the agenda of the municipality but practically there are still no implemented targeted local policies in the sector. At the same time, sustainable development is embedded in the National Tourism Development Strategy and is a priority of the World Tourism Organization. This necessitates the adaptation and implementation of established methods for the sustainable development of a tourist destination. Tourism in Botevgrad municipality has not been an up-to-date topic until recently, but given the changes and the opportunities of the region for its sustainable and complex development, as well as the prospects before the municipal administration for participation in projects and attracting investments and external financing, it is 
becoming more and more up-to-date. Moreover, no such research has been carried out so far. All this is subject to the attention of the municipal leadership and will be part of the development vision of the municipality in the tourism sector. [1]

The creation of a micro-planning scheme for a tourist destination is an effective mechanism for sustainable regional development. For this purpose, Tourist Zoning has been followed since the beginning of its development in our country from the 1960 s to the 1980 s, when more than 10 schemes were developed at a national level with academic or spatial planning. The study takes into account the main approaches to delineating the tourist areas in the different classifications, as well as the basic principles of tourist zoning formulated in scientific literature.

\section{Analysis of the tourist potential of the municipality of Botevgrad}

Botevgrad municipality, in order to outline the possibilities for micro-regionalization of the destination, covers the study of the external and internal factors of the environment that influence the development of tourism as well as an analysis and assessment of the resource potential, which it possesses.

The external environment outlines the macroeconomic framework. For the purpose of the survey, the positive and negative political, economic, socio-cultural and environmental impacts of tourism, as well as the technological factors related to the modern development of tourism, some trends in the sector's development and consumer behavior were studied. The survey outlines the opportunities and constraints for sustainable tourism development at a local level and its place in the macroeconomic framework. [2]

Internal factors include the location and good transport accessibility of the destination; economic characteristics whose good performance negatively affects entrepreneurship in tourism; the demographic characteristics that are influenced by the economic and social situation in the country, but the indicators are above average; the characteristics of education at local level and the availability of educational institutions in the larger settlements; the state of healthcare in the municipality, the social structure and the condition of the communal-household needs, taking into account the fact that the frequent stoppages of the water supply system in the municipality and the lack of water resources in some of the villages are a major limiting factor for the development of tourism. As a result of the study, the interaction of tourism with the other economic sectors in the municipality, its integration and its role in the overall microeconomic framework has been clarified. [2]

The tourism resources are generally identifiable with the conditions and factors that determine the tourist development and influence the tourist process. They are an essential part of the recreational factors of tourism. Recognized as an important quality of tourism resources in the context of sustainable development is that after their use by tourists, their qualities are preserved, not lost or destroyed and their utilization should meet the conditions for resource use in general: technical feasibility, economic necessity, social need and sufficient research. [3]

The analysis of natural resources shows that Botevgrad municipality has a mainly favorable geographic location, mild climate and good transport accessibility, which implies the successful development of various forms of tourism, but there are also limiting factors that have a negative impact: limited water resources, temperature inversions and the fogs typical for the Botevgrad valley. Protected areas are also of limited importance for tourism.

Anthropogenic tourism resources are manmade and have qualities to satisfy healing, recreational, cognitive, business or leisure needs. Botevgrad Municipality has a variety of cultural heritage sites: archaeological, historical and religious. The analysis shows that only a small part of them are attractive and accessible to tourists, which necessitates the municipal leadership to take measures to improve their functioning and accessibility.

The material and technical base of tourism is a basic unit in the process of creation, realization and consumption of the tourist product. The total number of accommodation places is 10 . Their number is limited and not evenly distributed. Categorized eating and entertainment establishments are large enough and characterized by variety. Most of them are with categories of one and two stars, but the offered conditions and services exceed the legal requirements for the respective category. The municipality has a good capacity of sports facilities, which are among the main reasons for attracting foreign visitors mainly to the 
city. The survey found that this factor could be used to maintain visitors and larger tourist flows if their use is combined during their stay with other attractions and events.

There are no eco-trails, cycling and other thematic routes on the territory of the municipality. The configurations of road and mountain routes, as well as a combination of both have been studied. The municipality is part of the Kom-Emine route, which can also increase its attractiveness by promoting hiking and cycling trails.

An analysis of the role of local authorities and other stakeholders for sustainable tourism development has been made, restrictions related to the administrative capacity of Botevgrad Municipality, the need to establish partnerships and interconnection with other stakeholders have been taken into account. Improvement of the organizational and management structure of the municipality can be accomplished through the consolidation of the existing municipal hotel "Bojenski urvich" and the future tourist information center in the municipal enterprise "Tourism".

The issue of tourism staff employed in tourist services is analyzed through the prism of the Territorial Recreation and Tourism system, where staff are diversified to management and executive personnel. The conclusions that can be drawn are related to the requirement for a high degree of professionalism and skills especially for managers, the increasing of human capacity and the development of tourism competence as a key factor, as well as the need to promote entrepreneurship. [4]

\section{PROPOSAL FOR TOURIST MICRO- REGIONALIZATION IN BOTEVGRAD MUNICIPALITY}

The tourist micro-regionation of the Botevgrad municipality and the creation of a regional tourist product are formulated as a second strategic priority in the Strategy for Sustainable Tourism Development of Botevgrad Municipality 2019-2025. It focuses on the planning of local tourism policies and the sustainable development of Botevgrad Municipality as an attractive, accessible and recognizable tourist destination, including on a wider scale, common tourist routes and products with its adjacent municipalities.

Various classifications of approaches to mapping out tourist areas are available in the scientific literature. For example, according to
Groters (2002, Fridgen, 1992), approaches can be: determining areas based on similar geographic features and climatic conditions; delineating areas with administrative or policy boundaries for planning purposes; formation of areas based on common historical development and traditions. [5]

Based on an analysis of a number of sources Marinov (1988) classifies approaches to tourism zoning as: resource approach - the tourist region is considered as a territory with the presence of tourism resources (used or potential); sectoral approach - the tourist region is considered to be a sector of economic importance and special attention is paid to specialization in tourist services. A tourist region is only an area in which tourism has become a specialized sector with which it participates in the territorial division of labour. Socio-geographical approach - in this case, tourism is seen not as an economic sector, but as a human activity, as one of the forms of recreation. The forming of such sociogeographical areas is based primarily on the movement of tourist flows or the distribution of needs. [6]

According to Smith (1989), the main approaches and areas of implementation are:

- Priory - outlined by researchers, designers or public authorities, often randomly and intuitively, without pre-formulated criteria and methodology. Very often these are existing political or administrative units that are marketed on the tourist market with an imposed or new name.

- Homogeneous - based on similarities, which are objectively established, according to predefined set of criteria. Most often such areas are tourist adapted sea coasts, mountains, etc.

- Functional - established on the basis of the links between the different territorial elements, common activities, imposed forms of interaction and exchange or patterns of tourist behaviour.

Given the main objective of creating tourist micro-regionalization - the development and marketing of the regional tourist product, the chosen approach implies the creation of homogeneous regions for achieving the uniqueness and identity which determines the choice of tourists, taking into account the geographic environment and the peculiarities in the historical development, as well as the territorial range of naturally formed spatial tourist formations and administrative 
boundaries of the lands. The starting point for identifying the marketing tourist regions at local level and their scope and specialization are the existing tourism zoning schemes from the past, scientific publications on the issue of tourism zoning. The basic requirements and criteria applied in the delineation of the tourist regions, in fulfilment of the current task, are limited to: the territorial coverage of the proposed areas corresponds to the real dimensions of tourism development (including existing organizational structures) and / or uncovered tourism potential; attractiveness the presence of significant attractions (exposed or potential) providing a sufficiently rich "menu" of tourist supply, which makes it possible to create a complex tourist product (product mix) and can keep visitors for at least a few days; infrastructure provision - the regions offer or have the potential to develop a complex of tourist services and related infrastructure for the needs of tourists and tourist business; homogeneity - relative similarity of natural and socio-economic conditions, resource potential and product structure, on the basis of which the outlined regions have a regional identity (to be perceived as whole units of large market segments, local authorities, tourist and tourism associations and associations); territorial integrity (compactness) - territorial fragmentation of the area and / or overlap with other areas is not allowed; Tolerance - striving to preserve the territorial integrity of existing regional associations and other voluntary formations between municipalities where this does not contradict the above criteria. [5]

Tourist micro-regionalization of the municipality of Botevgrad includes the development of a tourist micro-planning scheme of the municipality which is motivated by the necessity for the development of sustainable and competitive tourism, conducting a local tourism policy, taking into account the territorial specificities and specifics of the different parts of the municipality and effective marketing. In this way the tourist areas on the territory of the municipality can become recognizable for the potential tourists and can be successfully promoted on the domestic as well as the international market.

The concept of Bulgaria's tourism zoning has been developed in accordance with Art. 16, para. 1 of the Law on Tourism, the expected benefits of the creation of tourist areas and its implementation include:

- To fill the existing gap in marketing and destination management between national and local level;

- Reunification of resources and coherent actions for the development of a complex, diversified and competitive tourist product through regional interaction;

- Regionalization of national marketing in order to better meet the expectations, requirements and interests of different market segments;

More efficient participation on the potential tourist markets by presenting separate areas that are recognizable on the map.

There are nine tourist regions in Bulgaria, including Sofia Tourist Region, where Botevgrad municipality is included.

The tourist micro-regionalization at the level of the district or municipality should be in line with the tourist regions, differentiated according to the Tourism Act, at the national level.

Based on the detailed study of scientific literature and planning documents, the author has developed a tourism micro-region scheme including the following taxonomic units: tourist micro-region, tourist area, tourist core, tourist location and tourist point.

The defining of the borders is based on an administrative principle, thus microregionalization is goal-orientated and facilitates its use for planning and management purposes. It is resource-oriented and aims to map out homogeneous areas based on similarities between natural and anthropogenic tourism resources, taking into account cultural identity.

A tourist micro-region is a territory comprising an administrative area or part of an administrative area with good transport links, similar tourist resources and opportunities for creating a regional tourist product. In this case, a tourist micro-region, covering Botevgrad and its neighboring municipalities, which belong to the Sofia tourist region: Pravets, Etropole, Gorna Malina, Elin Pelin and Svoge. However, this possibility is not the subject of this study, as the management of the Sofia Tourist Region has not yet been set up and no discussions and consultations have been conducted during the surveys. A similar step, in line with the concept of national tourist zoning, should be undertaken at a later stage in the development of Botevgrad Municipality as a tourist destination. 
A tourist area is a territory which possesses borders and certain rules. It may cover a territory of two or more municipalities but may also be within only one municipality. Typical of the area's management regimes is that activities threatening tourism are not allowed on its territory. The management is mainly concerned with the traffic safety of tourists and providing emergency assistance if needed.

Within a tourist area, where touristic resources are concentrated according to similarity and conditions for tourism development, tourist core areas can be formed.
A tourist location is a specific site with historical, cultural, natural or cultural heritage tourist importance. It consists of a core part or a core (the specific monument / natural or tourist site), a buffer zone (landscaping, a park, a sanitary security zone) and a commercialservice area (meals, souvenirs, sanitary facilities, parking, etc.)

The vista point covers the view. In this case, it is the view, not the specific object, which is placed in the security regime. Accordingly, there is a ban on putting in place facilities that hide the view, diminish its scope or spoil the mystery of the place when we are talking about a sanctuary.

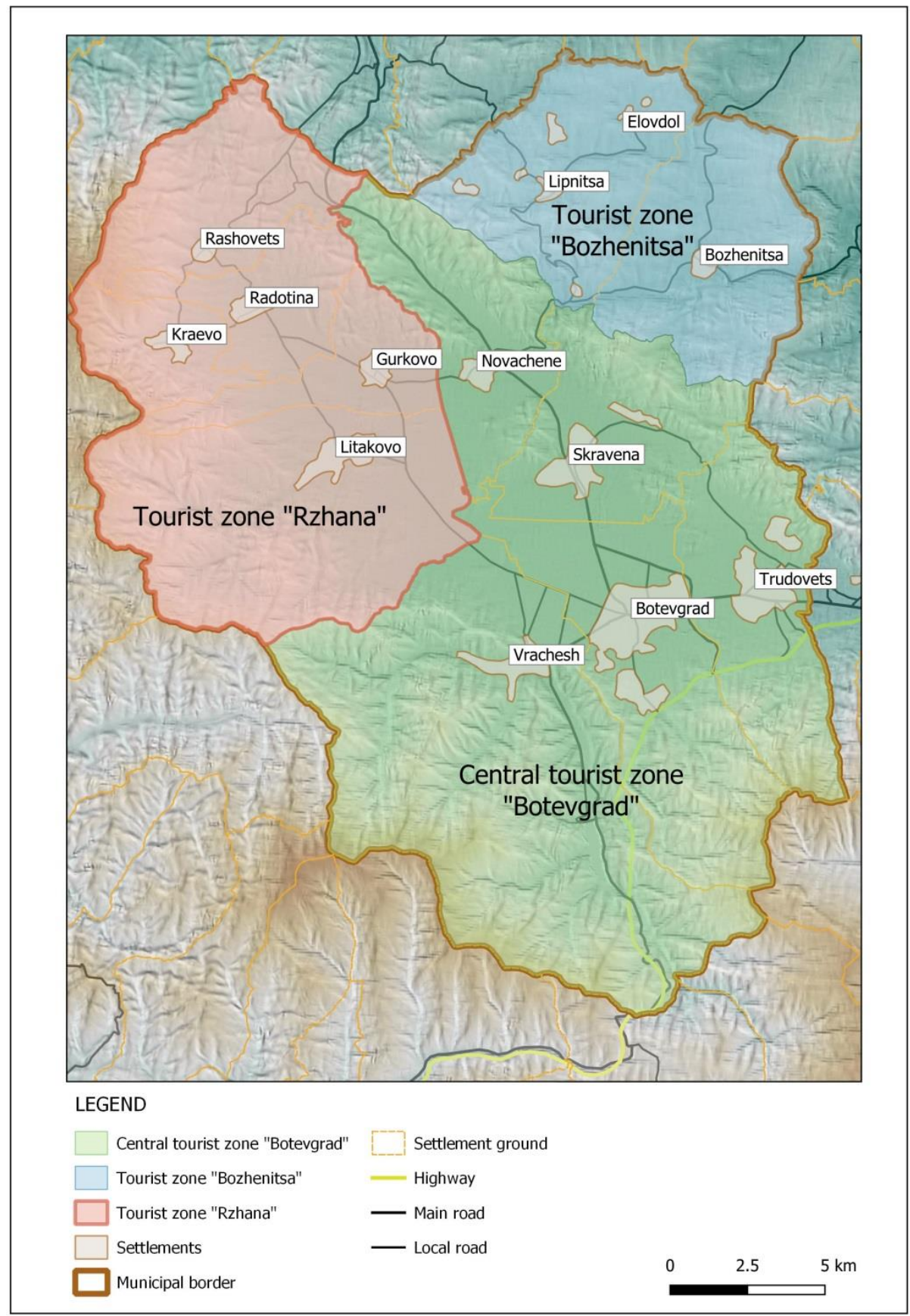

Figure 1. Toruist Micro-regionalization of Botevgrad Municipality 
Three tourist areas can be formed on the territory of Botevgrad Municipality. The tourist centre area Botevgrad, which occupies the central area, is located in the centre of the municipality and consists of three tourist cores covering: 1) Botevgrad, 2) Vratchesh, 3) Trudovets and Skravena. In each zone or tourist core, individual settlement formations and territories with concentrated tourist sites or resources are identified as tourist places. Each tourist destination, depending on the attractiveness and the uniqueness of the views it holds, may contain one or more tourist points.

The tourist area "Botevgrad" has a broader scope and includes the three tourist cores. It is fundamental and occupies a central place both territorially and functionally in terms of content. During the development of the individual tourist areas and tourist cores the transport accessibility has been taken into account and the connecting transport links are indicated. In addition, parameters are set regarding the remoteness of natural and cultural-historical sites from existing roads.

The formed tourist cores are introduced as an additional taxonomic unit, as they do not have a distinct self-image to define them as separate zones. The Botevgrad Central Tourist Zone is one of the largest villages in the municipality with direct communication from the Republican and European road network with the other two tourist areas, as well as with the municipalities Pravets and Mezdra. The area is collectively based on its historical content. The tourist areas "Bozhenitsa" and "Rjana" have their own character and integrity and appear as accompanying the central one.

Sustainable tourism development of the three areas in the Botevgrad municipality comprises of several basic steps: differentiation and marketing positioning; emphasis on the specific characteristics of the three tourist cores in the Botevgrad Central Tourist Area; exploration of tourist areas and tourist cores, digitalization of tourist spots, covering the view and giving out foreclosures for the placement of facilities to conceal the view, reduce its scope or spoil the mystery of the site. [1]

\section{The sustainable regional development of the tourist zones in Botevgrad municipality}

The author has explored the geographical and administrative boundaries of each of the three tourist areas as well as the existing transport links. During the development of the individual tourist zones and tourist cores transport accessibility has been taken into account and the connecting transport links are indicated. In addition, parameters are set regarding the remoteness of natural and cultural-historical sites from existing roads. To each tourist zone and to each tourist nucleus are listed and enumerated the possibilities for accommodation and eating, the main tourist sites and attractions that may be of interest to the tourists, the existing tourist routes and their condition, as well as the opportunities for sustainable tourism development of the specialized types of tourism, connected to local environmental conditions and tourism resources.

\section{Sustainable development of tourism in tourist area "Botevgrad"}

Botevgrad Tourist Area, apart from being a wider range and comprising the three tourist nuclei, is collectively in its historical content in the Historical Museum of the municipality and has active distinctive sectors of each of the villages, which reflect the strength and as central both by territory and by content. Opportunities for sustainable development of tourism are systematized in the three formed tourist nuclei.

Tourist Base "Botevgrad", covers the municipality of the town of Botevgrad and has excellent transport links with the other two nuclei, forming the central tourist zone.

The opportunities for sustainable tourism development in the tourist center "Botevgrad" include: sport and adventure tourism Botevgrad downhill, sport competitions and events; cycling; business and congress tourism - Arena Botevgrad, city hotels, MBBU; mountain hiking - Mount Bilo; volunteer tourism - scouting, WikiBotevgrad, animal care, forestation, cleaning, etc ; festival tourism - traditional and innovative events; Cultural Tourism - Historical Museum, Clock Tower, Zelinski Monastery and others.

Tourist core "Vrachesh" covers the village of Vrachesh. It is situated in the southwestern part of the Botevgrad valley at $400 \mathrm{~m}$ altitude, at the foot of Balkan Range Mountain and at the foot of Mount Murgash. The opportunities for sustainable tourism development include: mountain hiking and horse tourism - Mount Murgash; festival tourism - Barracks Festival; cultural tourism - Vratsa Monastery; hunting, fishing and volunteer tourism in the Vitinia 
State Hunting and Bebresh hunting and shooting, sustainable harvesting, education and educational activities related to game conservation and sustainable development.

Tourist core "Trudovets and Skravena" is located in the villages of Trudovets, Skravena and Novachene and extends along the external borders of their municipalities.

The opportunities for sustainable tourism development include: adventure and extreme tourism - horse, bicycle, off road, paratrike flying, balloon flying, balloon bungee jumping, ropeways; business, incentive and congress tourism - hotel complex Kredo; volunteer tourism - scouting, education and educational activities with children and young people, organized creative and sporting activities, care for nature, cleaning, etc .; cultural tourism monasteries, historical and archeological sites, traditional holidays; school and youth tourism study tours related to the Botev chetniks; school camps in the "Zdravets" horse base; equestrian and cycling; festival tourism.

\section{Sustainable development of tourism in tourist area "Bojenitsa"}

The "Bozhenitsa" tourist area covers the lands of the villages of Bozhenitsa, Lipnitsa and Elov dol. Opportunities for sustainable tourism development are relatively large but there are still significant constraints.

The tourist area includes the following tourist places: Bozenitsa village with the archaic cell school; the Bebrech protected area with the climbing rocks and canyons of the Bebresh River; fortress "Bojenishki urvich" and "School Forest" reserve; village of Lipnitsa; village of Elov Dol and the surrounding area.

The opportunities for sustainable tourism development in the Bozenitza tourist area include practicing: ecotourism - tours and events related to protected areas and biodiversity; adventure and extreme tourism equestrian, bicycle, rock climbing, speleotourism, canyoning; mountain hiking; volunteer tourism - international camps, team buildings, scouting activities, etc .; event tourism - adventure pentathlon, folklore fair, motto fair; cultural tourism - cell school, archaeological sites, craft workshops; school and youth tourism - summer schools, green and white schools, student and student excursions and practices; artistic and craftsmanship; fishing tourism - the Bebresh River near the village of Bozhenitsa.

\section{Sustainable development of tourism in the tourist area "Rjana"}

The tourist area "Rjana" covers the lands of the
ALEXOVA D.

villages of Litakovo, Gurkovo, Radotina, Rashkovo and Kraevo and is named after the Rzana Mountain, which is located in the northern branch of the Murgashki part of the Western Balkan Range. It is also a western geographical boundary of the secluded tourist zone. The opportunities for sustainable tourism development in the tourist area "Rjana" are mostly in perspective.

The tourist area covers the following tourist places: Gurkovo village with a micro dam; wetlands near Gurkovo; protected area "Dreneto"; the center of the village of Litakovo with the church; wetlands near the village of Litakovo; The Brotherly mound and the vows near the village of Litakovo; village of Kraevo; Rashkovo village; village of Radotina. The following specialized types of tourism can be developed: mountain hiking - routes from each village to Rjana mountain; adventure tourism horse, bicycle, off road; cultural tourism churches, vows, local holidays; fishing tourism - Gurkovo small dam, fishpond; volunteer tourism - marking of tourist routes, cleaning, forestation; ecotourism - bird-watching in the "Dreneto" Protected Site; industrial tourism - a visit to "Yablena Natura" - introduction to the growing of fruit crops, the production process of organic products and tasting.

\section{CONCLUSION}

In the study of the existing schemes for tourism zoning the main advantages and omissions have been taken into account and on the basis of the analysis made a tourist scheme has been developed for micro-regionalization in the borders of Botevgred municipality, which comprises four spatial levels: tourist zone, tourist core, tourist spot and tourist point. A cartographic GIS study method is applied. A mapping scheme has been developed indicating the location, boundaries and transport links of the separate tourist areas and the location of the other taxonomic units in each of the distinct zones.

The practical application of the theoretical scheme for micro-regionalization of Botevgrad municipality, comprising several basic steps: differentiation of the three tourist zones and their marketing positioning; Emphasis on the specific characteristics of the three tourist cores in the Botevgrad Central Tourist Zone; exploration of tourist areas and tourist nuclei, digitization of tourist spots, viewing and writing foreclosures for facilities that hide the view, reduce its scope, or spoil the mystery of the site. 
It is essential to develop the Botevgrad municipality's product policy in relation to the possibilities of offering specialized types of tourism, according to the specific features and the tourist potential of the separate tourist areas. This will help recognize Botevgrad not only as an industrial but also as a tourist destination, and the integration of tourism with the rest of the economic sectors will have an image effect and can be used as a lever for additional stimulus for the prosperity of the municipality. This requires systematic and purposeful local policies in the sector, based on the adaptation and implementation of methodologies for the sustainable development of a tourist destination.

The model for sustainable tourism development in the municipality of Botevgrad can be applied in the planning and development of tourism both in the local tourism policies of other municipalities with similar indicators and at the national level by the Ministry of Tourism and the organizations for managing the tourist regions.[7]

\section{ACKNOWLEDGEMENTS}

This publication is financed by Science research fund through project “,Model Development and Testing for Monitoring and Evaluation of Sustainable Tourism Development in Bulgaria (after the example of national resorts)" financed by the National Fund „Scientific Research“, contract No КП06-H25/3 from 13.12.2018.

\section{REFERENCES}

1. Alexova, D. Sustainable Development of Tourist Destination on Example of Botevgrad Municipality, Quaestus, Numerul 14, Anul 8, 2019, pp. 45-61, ISSN 2285-424X
ALEXOVA D.

Bachvarov, M., Eurev P. The Specificity of Territorial Recreational Units. - Problems of Geography, 1991.

2. Strategy for Sustainable Development of Tourism in Botevgrad Municipality, 2017, Last modified December 22, 2018 In: http://botevgrad.bg/data/pages/files/154392 9139.pdf 2019-2025, Last modified January 7 , 2019 ,

In: http://botevgrad.bg/data/pages/files/154392 9139.pdf?\%D0\%B0=46

3. Vodenka, Asenova, Introduction to Tourism, Ed. MATCOM, 2011: pp. 125133

Dinev, L. 1974. Concept of Tourist Zoning of Bulgaria, In Yearbook of Sofia University, GGF, ed.. 2, Geography, vol.. 66, 1974

4. Vodenska M. The model of Territorial Recreation and Tourism system as the Main Object of Research in the Geography of Tourism and the Place of the Influences of Tourism in it, in Jubilee collection Geography - Yesterday, Today, Tomorrow, Ed.liment Ohridski, S. 2004.

5. Dokramadzhieva, E. 2003.A Concept of Sustainable Tourism Development as Part of The Global Idea of Sustainability in the Modern World - Yearbook of Sofia University, ed. 2, vol. 93, 2000

6. Evrev, P., Marinov V.., Vodenska, M. Asenova, M., Dokramadzhieva E. and others, A Concept for the Territorial Development of Tourism in Bulgaria. Preliminary analysis. S., NCTR, MRDPW, 2003.

7. Popova, N., Spatial Characterization and Peculiarities of the Resource Potential for Development of Cultural and Historical Tourism in Bulgaria, IBS PRESS, S., 2012 